\title{
Seasonal Influence on Yield of Maize and Its Validation with CERES-Maize Model
}

\author{
M. Swetha Sree*, T. Prathima, V. Rajarajeswari and P. Latha \\ Department of Crop Physiology, S.V Agricultural College, Tirupathi, 517502, \\ Andhra Pradesh, India \\ *Corresponding author
}

\section{A B S T R A C T}

Keywords

Crop growth model, Season, DSSAT,

CERES,

Simulation, Yield

Article Info

Accepted:

08 June 2018

Available Online:

10 July 2018

\begin{abstract}
It would be preferable to use a reliable crop growth model for studies on climate change impact assessment. The objectives of this study were to evaluate simulation performance for models CERES-Maize included in the DSSAT model (version 4.5) in terms of yield. Three hybrids D.S 900M, Pinnacle and CP818 were grown under four dates June II FN, July I FN, July II FN and August I FN during kharif season, 2016 at S.V. Agricultural college, Tirupati to study the 'Seasonal influence on yield of maize and its validation with CERES-Maize model'. The results indicated that among the hybrids Pinnacle recorded numerically higher yield $\left(3006.58 \mathrm{~kg} \mathrm{ha}^{-1}\right)$ than D.S $900 \mathrm{M}$ but was significantly higher than CP818. Among the dates of sowing $\mathrm{D}_{1}$ (June II FN) recorded significantly higher yield (3684.36 kg ha ${ }^{-1}$ ) than $\mathrm{D}_{2}, \mathrm{D}_{3}$ and $\mathrm{D}_{4}$. CERES Maize model validated excellent for grain yield. The simulated and observed yields are within the bounds of experimental uncertainity. CERES Maize model v.4.5 can be used to forecast maize yield in Southern agro-climatic conditions.
\end{abstract}

\section{Introduction}

Climate change is a global phenomenon and has now emerged as one of the most burning environmental issue to confront the humanity. The fifth assessment report of Intergovernmental Panel on Climate Change (IPCC, 2013) makes it clear that the global average temperature has increased by $0.74^{\circ} \mathrm{C}$ over the last 100 years and projected increase is about 1.8 to $4.0^{\circ} \mathrm{C}$ by 2100 .

Maize growth is affected by temperature conditions during vegetative and reproductive stages (Hardacre and Turnbull, 1986). Under future climate conditions, e.g., at the end of 21 st century, temperatures during growing seasons in the tropic and subtropics would exceed the most extreme temperatures recorded at present.

High temperature during the reproductive stage would reduce the number of kernels per ear because the number of ovules that could have been fertilized and developed into kernels would decrease result in the decline of crop yield and quality (Schoper et al., 1987). 
To better understand the responses of crops to their environments, computer models are being used to study both the simple and complex aspects of this plant system. Crop growth and yield are the outcomes of complicated interactions between plant and environments including soil and weather, which makes it challenging to assess the seasonal impacts on crop growth and yield through field experiments.

Crop growth simulation models facilitate quantitative understanding of the effects of environmental factors and agronomic management on crop growth and yield. Crop simulation models have been used for many different applications in various countries around the world. A well validated crop simulation model can simulate crop growth, development and yield with accuracy. It also serves as a viable tool for optimizing crop production. The Decision Support System for Agro technology Transfer (DSSAT v 4.5) is a comprehensive decision support system (Hoogenboom et al., 2010) that includes the CERES-Maize model (Jones et al., 2003).

\section{Materials and Methods}

Keeping above in view, a field experiment was conducted during kharif 2016 at S.V Agricultural College, Tirupathi to study the 'Seasonal influence on phenology and growing degree days in relation to yield of maize and its validation with CERES-Maize model.' The soil of the experimental site was sandy loam in texture, neutral in soil reaction, low in available nitrogen and organic carbon, high in phosphorus and medium in potassium. The experiment was laid out in a split plot design with twelve treatments and replicated thrice. Three maize hybrids D.S 900M, Pinnacle and CP818 with four dates of sowing (June II FN, July I FN, July II FN and August I FN).
For Validation the Decision supporting system for Agro-technology Transfer (DSSAT) v4.5 CERES-Maize model was used. DSSATv4.5 is an upgrade model of technology DSSAT v4.0. DSSAT v4.5 is MS Window-based model. The preferred operating system is Windows XP. Performance of the model was evaluated using absolute and normalized root mean square error (RMSE and NRMSE), and the Wilmot d index (Willmott et al., 1985).

\section{Results and Discussion}

\section{Kernel yield and growing degree days}

The results revealed that Kernel yield and GDD accumulation was higher in case of Pinnacle $\left(3006.6 \mathrm{~kg} / \mathrm{ha}, 3053.3^{\circ} \mathrm{C}\right)$ followed by D.S $900 \mathrm{M}\left(2748.9 \mathrm{~kg} / \mathrm{ha}, 3049.1^{\circ} \mathrm{C}\right)$ and CP818 (2678.4 kg/ha, $\left.2994.1^{\circ} \mathrm{C}\right)$ respectively. Therefore Pinnacle performance was superior to D.S 900M and CP818 (Table 1). The shifting of sowing dates corresponds to fluctuations in temperatures either lengthening or shortening of the growing periods. Among the dates of sowing D1 (June II FN) recorded highest kernel yield and GDD (3684 kg/ha, $3170.4^{\circ} \mathrm{C}$ ) followed by D2, D3 (July II FN) and $\mathrm{D}_{4}$ recorded lowest kernel yield and GDD (1724 kg/ha, $2079.6^{\circ} \mathrm{C}$ ).

Early sowing (June II FN) significantly influenced the yield of maize than subsequent dates of sowing because of higher accumulation of heat units. Delay in sowing resulted in reduction of kernel yield which might be due to minimum accumulation of heat units. Therefore the Second fortnight of June is always better to avoid abiotic stress and biotic stress problems in maize. Similar variability was also reported by Pandey et al., (2010), Girijesh et al., (2011) and Ahmad et al., (2016). 
Table.1 Comparison of kernel yield and growing degree days of maize

\begin{tabular}{|c|c|c|}
\hline \multirow[t]{2}{*}{ Treatments } & \multirow[b]{2}{*}{ Kernel yield (kg/ha) } & \multirow[b]{2}{*}{ Growing degree days } \\
\hline & & \\
\hline \multicolumn{3}{|l|}{ Hybrids } \\
\hline $\mathrm{H}_{1}:$ D.S 900M & 2748.9 & 3049.1 \\
\hline $\mathrm{H}_{2}$ : Pinnacle & 3006.6 & 3053.3 \\
\hline $\mathrm{H}_{3}: \mathrm{CP818}$ & 2678.4 & 2994.7 \\
\hline $\mathrm{CD}(\mathrm{P}=\mathbf{0 . 0 5})$ & 304.7 & - \\
\hline \multicolumn{3}{|l|}{ Dates of Sowing } \\
\hline$D_{1}:$ June II FN & 3684.4 & 3170.4 \\
\hline$D_{2}:$ July I FN & 3207.7 & 2990 \\
\hline$D_{3}$ : July II FN & 2628.8 & 2920.8 \\
\hline$D_{4}:$ August I FN & 1724.3 & 2079.6 \\
\hline $\mathrm{CD}(\mathrm{P}=\mathbf{0 . 0 5})$ & 238.8 & - \\
\hline
\end{tabular}

Table.2 Comparison of simulated and observed grain yield $\left(\mathrm{kg} \mathrm{ha}^{-1}\right)$ in maize

\begin{tabular}{|c|c|c|c|}
\hline Treatment & Simulated & Observed & Error (\%) \\
\hline \multicolumn{4}{|l|}{ D.S 900M $\left(\mathrm{H}_{1}\right)$} \\
\hline$D_{1}:$ June II FN & 3529 & 3748 & -5.8 \\
\hline$D_{2}:$ July I FN & 3294 & 3048 & 8.1 \\
\hline $\mathrm{D}_{3}:$ July II FN & 2766 & 2339 & 18.3 \\
\hline $\mathrm{D}_{4}$ : August I FN & 1935 & 1860 & 4 \\
\hline \multicolumn{4}{|l|}{ Pinnacle $\left(\mathrm{H}_{2}\right)$} \\
\hline$D_{1}$ : June II FN & 3647 & 3666 & -0.5 \\
\hline $\mathrm{D}_{2}:$ July I FN & 3769 & 3430 & 9.9 \\
\hline$D_{3}:$ July II FN & 3693 & 3244 & 13.8 \\
\hline $\mathrm{D}_{4}$ : August I FN & 1863 & 1686 & 10.5 \\
\hline \multicolumn{4}{|l|}{$\mathrm{CP} 818\left(\mathrm{H}_{3}\right)$} \\
\hline$D_{1}:$ June II FN & 1864 & 3640 & -1.4 \\
\hline$D_{2}:$ July I FN & 3055 & 3145 & -2.9 \\
\hline $\mathrm{D}_{3}:$ July II FN & 2417 & 2302 & 5 \\
\hline $\mathrm{D}_{4}$ : August I FN & 1407 & 1626 & -13.5 \\
\hline Average & 2769.92 & 2811.7 & \\
\hline $\mathrm{Sd} \pm$ & 846.1 & 802.8 & \\
\hline \multicolumn{4}{|l|}{ Test parameter } \\
\hline MBE & -102 & & \\
\hline MAE & 202 & & \\
\hline RMSE & 244.3 & & \\
\hline NRMSE & 8.6 & & \\
\hline d-stat & 0.9 & & \\
\hline
\end{tabular}


Fig.1 Simulated vs observed values for grain yield $\left(\mathrm{kg} \mathrm{ha}^{-1}\right)$ of maize hybrids at different dates of sowing

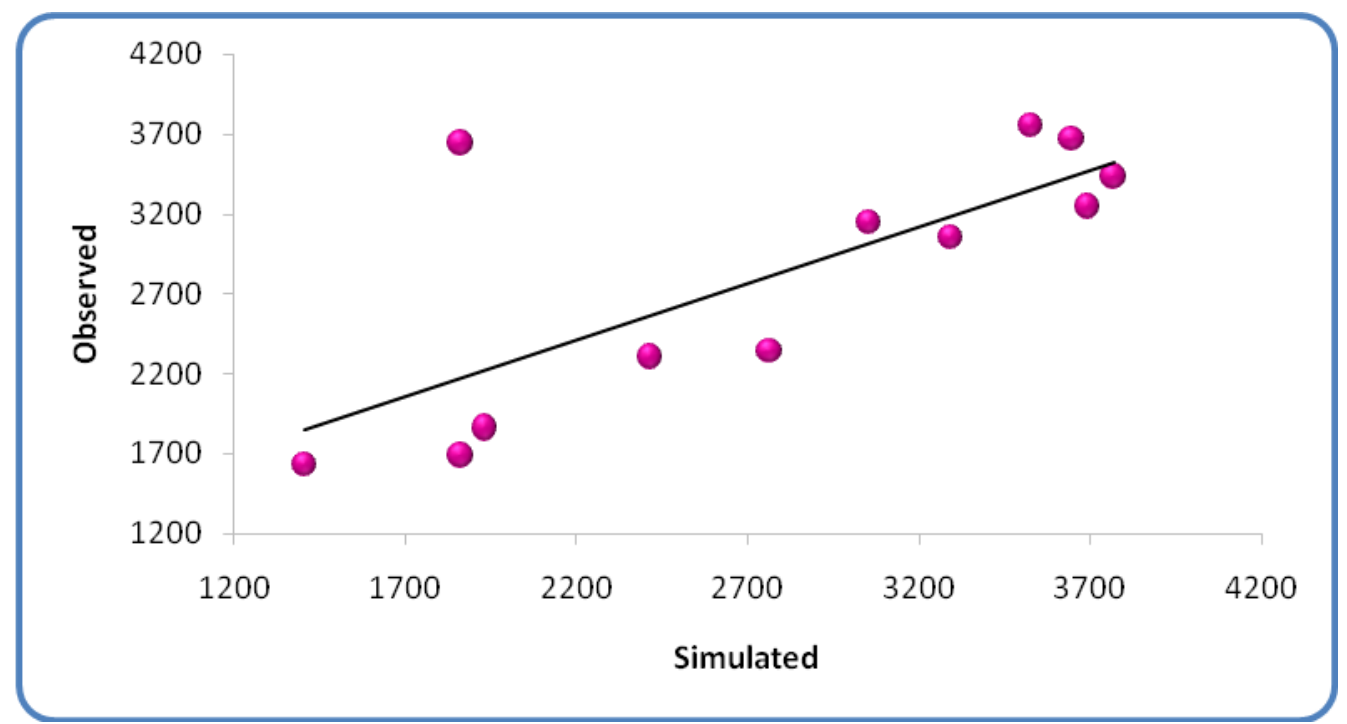

\section{Validation with CERES -maize model}

Using the data obtained from the field experiments conducted during kharif, 2016. The experimental file (AGCG1601MZ), weather file (AGCG2016), soil file (AGCG060016) were created for CERESMaize validation. The crop genetic coefficients already developed for the three hybrids were also used as input for CERESMaize validation v 4.5.

\section{Grain yield $\left(\mathrm{kg} \mathrm{ha}^{-1}\right)$}

The data on grain yield $\left(\mathrm{kg} \mathrm{ha}^{-1}\right)$ was computed at all the treatments of maize Table 2 and Figure 1. The results showed that grain yield of maize varied from $3748 \mathrm{~kg} \mathrm{ha}^{-1}$ (June II FN, D.S 900M) to $1626 \mathrm{~kg} \mathrm{ha}^{-1}$ (August I FN, CP818) while the model simulated grain yield ranged from $3769 \mathrm{~kg} \mathrm{ha}^{-1}$ (July I FN, Pinnacle) to $1407 \mathrm{~kg} \mathrm{ha}^{-1}$ (August I FN, CP818).

The percent error between simulated and observed yield ranged from -0.5 (June II FN, Pinnacle) to 18.3 (July II FN, D.S 900M). The error percentage between simulated and observed for kernel yield was lower at First and second dates of sowing (June II FN and July I FN) for all the hybrids compared to third and fourth date of sowing (July II FN and August I FN). Evaluation of the model showed that observed mean yield was 2811.2 \pm 802.8 during the crop season while the simulated mean yield was $2769.9 \pm 846.1$. The MAE computed was found 202 and the RMSE was $244.3 \mathrm{~kg} \mathrm{ha}^{-1}$ which shows reasonably good agreement with the observed values.

During the crop growth season simulation can be considered excellent with NRMSE values being less than 10 per cent. The d-index value was 0.99 indicating that the model was able to simulate grain yield well within the bounds of experimental uncertainity. Similar variability was also reported by Tojoseller et al., (2007), Ramawath et al., (2012) and Leela et al., (2014).

\section{References}

Ahmadh, I., Shehzad, M.A.B., Muhamadh, A., Muhamadh, A., Allahwasya and Hussain,

S.Z.

2016. 
Agrometerological, phenological and yield response of spring maize as influenced by foliar application of different plant growth regulators under suboptimal temperature of Faisalabad, Pakistan. Journal of Agrometeorology. 18(2): 315-319.

Girijesh, G.K., A.S. Kumaraswamy, A.S., Sreedhar, Dinesh kumar, S.M., Vageesh, T.S and Rajashekarappa, K.S. 2011. Heat unit utilization of kharif maize in transitional zone of Karnataka. Journal Agrometeorology. 13(1): 43-45.

Hardacre AK, Turnbull HL. 1986. The growth and development of maize (Zea mays L.) at five temperatures. Ann.

Hoogenboom, G., Jones, J.W., Wilkens, P.W., Porter, C.H., Boote, K.J. and Hunt, L.A. (2010). Maize Cultivar Specific Parameters for Decision Support System for Agrotechnology Transfer (DSSAT) Application in Tanzania. American Journal of Plant Sciences, Decision Support System for Agrotechnology Transfer (DSSAT) Version 4.5, Honolulu, University of Hawai, CD ROM.

Jones, J.W., Hoogenboom, G., Porter, C.H., Boote, K.J., Batchelor, W.D., Hunt, L.A., Wilkens, P.W., Singh, U., Gijsman, A.J., Ritchie, J.T. 2003. DSSAT Cropping System Model. European Journal of Agronomy. 18: 235-265.

Leela, P.R, Sreenivas, G and Reddy, R.D. 2014. Application of CSM-CERESMaize model to define a sowing window and nitrogen rates for rainfed maize in semi-arid environment. International Journal of Bio resource and Stress Management. 5(2): 181185.

Pandey, I.B., Pandey, R.K., Dwivedi, D.K and Singh. R.S. 2010. Phenology, heat unit requirement and yield of wheat (Triticum aestivum) varieties under different crop growing environment. Indian Journal of Agricultural Sciences. 80: 136-140.

Ramawat, N., Sharma, H.L and Kumar, R. 2012. Simulation, Validation and application of CERES-Maize model yield maximization of maize in north western Himalayas. Applied Ecology and Environmental Research. 10(3): 303-318.

Schoper JB, Lambert RJ, Vasilas BL. 1987a. Pollen viability, pollen shedding, and combining ability for tassel heat tolerance in maize. Crop Sci. 27: 2731

Tojosoler, C.M, Paulo, C.S and Hoogenboom. 2000. Application of the CSMCERES-Maize model for planting date evaluation and yield forecasting for maize grown off-season in a subtropical environment. European Journal of Agronomy. 27: 165-177.

Willmott, C.J., Ackleson, S.G., Feddema, J.J., Klink, K.K., Legates, J. and Rowe, C.M. 1985. Statistics for evaluation and comparison of models. Journal of Geophysical Research of Oceans. 90: 8995-9005.

\section{How to cite this article:}

Swetha Sree, M., T. Prathima, V. Rajarajeswari and Latha, P. 2018. Seasonal Influence on Yield of Maize and Its Validation with CERES-Maize Model. Int.J.Curr.Microbiol.App.Sci. 7(07): 923-927. doi: https://doi.org/10.20546/ijcmas.2018.707.111 